University of Nebraska - Lincoln

DigitalCommons@University of Nebraska - Lincoln

USDA National Wildlife Research Center - Staff

Publications

U.S. Department of Agriculture: Animal and Plant Health Inspection Service

$12-1999$

\title{
Wildlife-Caused Losses for Producers of Channel Catfish Ictalurus punctatus in 1996
}

Alice P. Wywialowski

Animal and Plant Health Inspection Service, U.S. Department of Agriculture

Follow this and additional works at: https://digitalcommons.unl.edu/icwdm_usdanwrc

Part of the Environmental Sciences Commons

Wywialowski, Alice P., "Wildlife-Caused Losses for Producers of Channel Catfish Ictalurus punctatus in 1996" (1999). USDA National Wildlife Research Center - Staff Publications. 810.

https://digitalcommons.unl.edu/icwdm_usdanwrc/810

This Article is brought to you for free and open access by the U.S. Department of Agriculture: Animal and Plant Health Inspection Service at DigitalCommons@University of Nebraska - Lincoln. It has been accepted for inclusion in USDA National Wildlife Research Center - Staff Publications by an authorized administrator of DigitalCommons@University of Nebraska - Lincoln. 


\title{
Wildlife-Caused Losses for Producers of Channel Catfish Ictalurus punctatus in 1996
}

\author{
ALICE P. WYWLALOWSKI \\ Risk Analysis Systems, Unit 117, Policy and Program Development, \\ Animal and Plant Health Inspection Service, U. S. Department of Agriculture, Riverdale, \\ Maryland 20737-1238 USA
}

\begin{abstract}
The National Agricultural Statistics Service surveyed by telephone and mail in January and February 1997 all known producers of channel catfish Ictalurus puncfafus to acquire curent information about wildlife-caused losses in calendar year 1996. Many producers tried to prevent wildlife-caused losses of their catfish by sthooting (57\%), vehicle patrol (55\%), or frightening (36\%), at an estimated cost of $>\$ 5$ million. Yet, $69 \%$ of catfish producers cited some wildlife-caused losses. Birds were most frequently cited as a cause of losses, and double-crested cormorants Phalacrocorax auritus was the species cited most frequently (53\%). The next most frequently cited birds were herons Ardea spp. (48\%), egrets Egretta spp. (16\%), and pelicans Pelecantus spp. (8\%). Muskrats Ondatra zibethicus were cited by $10 \%$ of producers, primarily for danaging dikes and roads. The main problems caused by wildlife were feeding on catish $(67 \%)$, injuring catfish $(40 \%)$ or disturbing feeding patterns of the catfish $(23 \%)$. The total estimated cost of losses was $\$ 12$ raillion. Overall, wildlife damage and damage prevention ray have cost catfish producers $>\$ 17$ million, about $4 \%$ of the total $\$ 425$ million of catfish sales in 1996 . Of the $44 \%$ of all catfish producers who were familiar with Wildlfe Services (WS), $51 \%$ had ever contacted WS for assistance, $55 \%$ used methods suggested by WS to reduce their losses, and $40 \%$ received direct assistance from WS in 1996 . Mississippi producers, who most frequently received direct assistance from $W S$, had proportionately lower wildlife-caused losses.
\end{abstract}

Catfish production is a growing industry in this country. Production has increased from $<7$ million pounds processed in 1970 to 518 million pounds processed in 1996 (USDA 1998). Of all agricultural producer groups surveyed in 1995, trout and catfish producers cited the greatest percentage of wildlife-caused losses ( $>70 \%$, Wywialowski 1998). To further understand their problems and help identify solutions, WS, (formerly Animal Damage Control) (ADC), Animal and Plant Health Inspection Service (APHIS), United States Department of Ag- riculture (USDA) contracted with the National Agricultural Statistics Service (NASS), USDA in 1997 to survey catfish producers about losses caused by wildlife to their catfish production operations.

\section{Materials and Methods}

In January and February of 1997, the NASS surveyed catfish producers about wildlife-caused losses during 1996. A postcard was sent to potential respondents in December of 1996, advising them that an enumerator would be calling them for information, or the survey would be arriving in the mail, as some producers requested. Surveys were conducted primarily by telephone, but a small proportion of producers received mail surveys. Data were analyzed for six regions, each with a sample of $>100$ respondents (Fig. 1) using SPSS version 7.5 software (SPSS Inc., Chicago, Illinois, USA).

The cost of loss prevention and sustained losses was the sum of cited dollar values for each region plus an adjustment equivalent to the proportion of total catfish sales in each region as determined by NASS sales statistics. That is, cited cost $\mathrm{r}_{\mathrm{r} i-6} /$ adjusted cost $_{\mathrm{r} 1-6}=$ total sales of respondents ${ }_{\mathrm{rl}-6} /$ adjusted total catfish sales ${ }_{r 1-6}$. For each producer, their wildlife-caused income loss was equal to their estimated dollars spent on preventative methods plus the damage sustained to their operation or actual loss of catfish.

Differences in the proportions among regions were determined using the Bonferroni Least Significant Difference Test at $P \leq$ 0.05 . Differences in the distribution of 2 variables relative to each other were deter- 


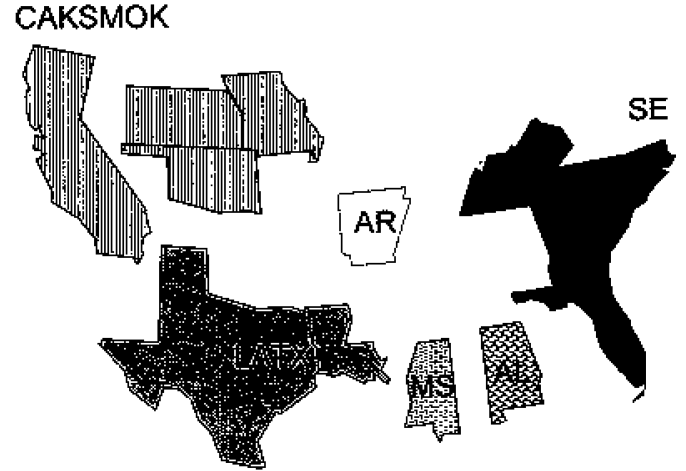

FIGURE 1. Regions for catfish production in 1996.

mined using the Maximum Likelihood Ratio Test (MLR) and correlations were determined using the Pearson Correlation Coefficient $(R)$. Differences between groups in dollars or percent total sales were determined using unpaired unequal variance $t$ tests $(t)$.

\section{Results \\ Response Rate and Regions}

Of the 1,465 producers on the NASS lists of catfish producers in the 15 states sur- veyed (Fig. 2), 1,008 (68.8\%) agreed to complete the survey; $15 \%$ of those on the list were not involved in catfish production in 1996 (non-producers, $N=214$ ) and were eliminated; $17 \%$ of listed producers failed to complete the wildlife-caused losses portion of the survey or could not be contacted by phone during the 2-wk sampling period ( $N=243$ ). These producers were not included in the analyses, but were adjusted proportionately for calculation of dollar values as described in the methods. The response rate varied among states and regions, but the overall response rate for all known producers of catfish $(N=1,251)$ was $80.6 \%$. The majority of catfish producers who responded were in Mississippi ( $N$ $=300)$, followed by Alabama $(N=163)$, and Arkansas $(N=117)$. The remaining states had $<100$ respondents.

\section{Loss Prevention}

Producers spent a substantial amount of effort to prevent wildlife-caused losses of their catfish. The majority of producers (68\%) used one or more methods to prevent

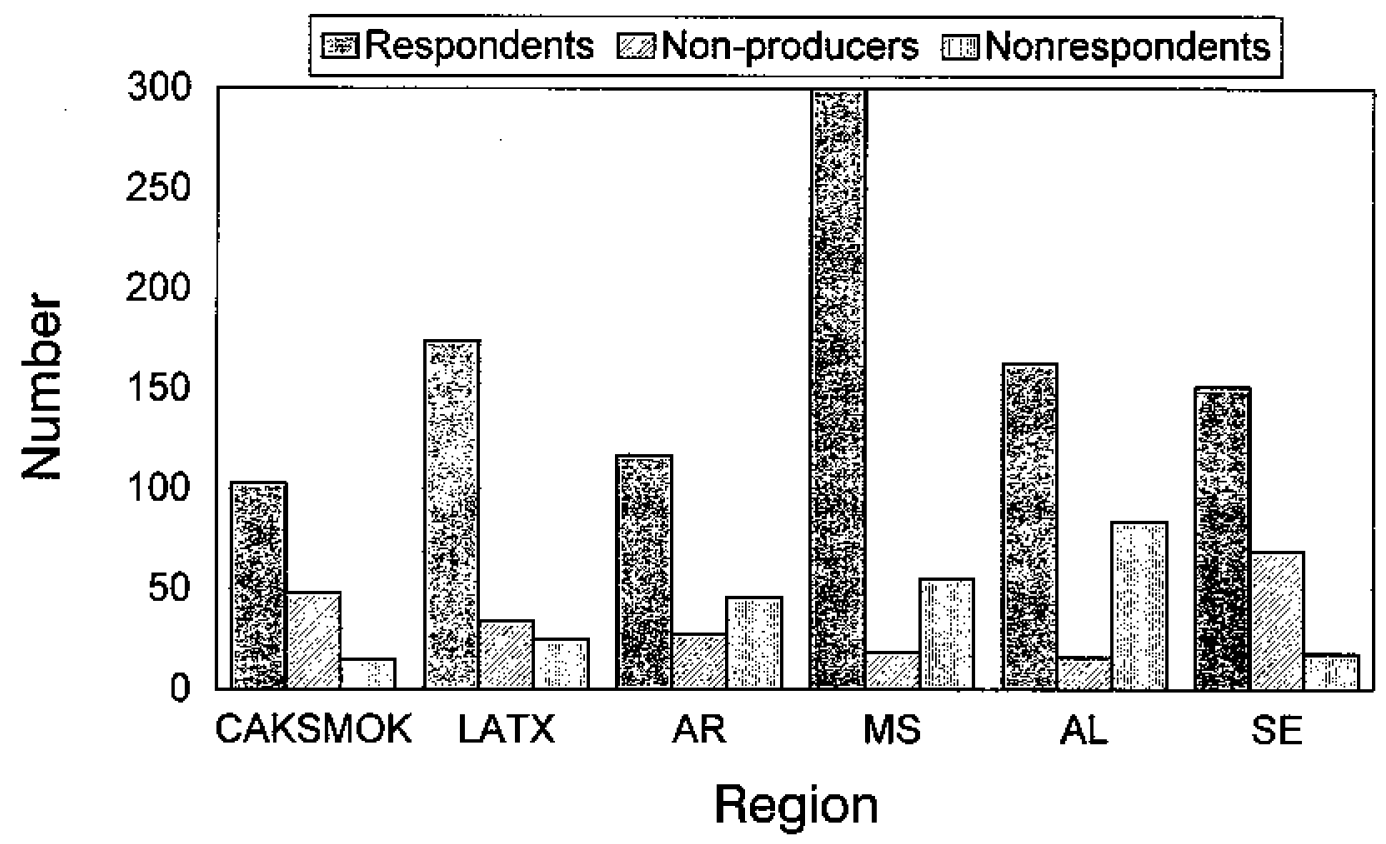

FIGURE 2. Respondents, non-producers, and non-respondents by region in 1996. 
TABLE 1. Percent of catfish producers that used methods to prevent wildlife-caused losses of catfish by regions in 1996. Regions without the same letter by their percent differ significantly within rows by the Bonferroni Least Significant Difference Test at $\mathrm{P} \subseteq 0.05$.

\begin{tabular}{|c|c|c|c|c|c|c|c|}
\hline \multirow[b]{2}{*}{$\begin{array}{l}\text { Method of loss } \\
\text { prevention }\end{array}$} & \multicolumn{7}{|c|}{ Region } \\
\hline & $\begin{array}{c}\text { West }{ }^{\mathrm{t}} \\
N=103 \\
(\%)\end{array}$ & $\begin{array}{c}\text { LATX }^{2} \\
N=174 \\
(\%)\end{array}$ & $\begin{array}{c}\text { Arkansas } \\
N=117 \\
(\%)\end{array}$ & $\begin{array}{c}\text { Mississippi } \\
N=300 \\
(\%)\end{array}$ & $\begin{array}{c}\text { Alabama } \\
N=163 \\
(\%)\end{array}$ & $\begin{array}{c}\text { Southeast }^{3} \\
N=151 \\
(\%)\end{array}$ & $\begin{array}{c}\text { All } \\
N= \\
1,008 \\
(\%)\end{array}$ \\
\hline Any preventive method & $63.1 \mathrm{c}$ & $59.2 \mathrm{c}$ & $82.9 \mathrm{ab}$ & $85.0 \mathrm{a}$ & $68.1 \mathrm{bc}$ & $35.8 \mathrm{~d}$ & 68.0 \\
\hline Shooting & $45.6 \mathrm{c}$ & $45.4 \mathrm{c}$ & $71.8 \mathrm{ab}$ & $75.0 \mathrm{a}$ & $58.9 \mathrm{bc}$ & $25.8 \mathrm{~d}$ & 56.5 \\
\hline Vehicle patroi & $44.7 \mathrm{~b}$ & $47.7 \mathrm{~b}$ & $76.1 \mathrm{a}$ & $78.0 \mathrm{a}$ & $47.2 \mathrm{~b}$ & $16.6 \mathrm{c}$ & 55.0 \\
\hline Frightening & 31.1 bc & $26.4 \mathrm{c}$ & 44.4 ab & $49.3 a$ & $42.3 \mathrm{ab}$ & $10.6 \mathrm{~d}$ & 36.0 \\
\hline Roost dispersal & $3.9 \mathrm{~b}$ & $7.5 \mathrm{~b}$ & $12.8 \mathrm{~b}$ & $32.0 \mathrm{a}$ & $5.5 \mathrm{~b}$ & $2.6 \mathrm{~b}$ & 14.0 \\
\hline Modify management & $21.4 \mathrm{a}$ & $8.0 \mathrm{bc}$ & $9.4 \mathrm{abc}$ & $9.3 \mathrm{bc}$ & $14.1 \mathrm{ab}$ & $4.0 \mathrm{c}$ & 10.3 \\
\hline Other & $15.5 \mathrm{a}$ & $4.6 \mathrm{bc}$ & $0.9 \mathrm{c}$ & $5.0 \mathrm{bc}$ & $6.1 \mathrm{bc}$ & $11.9 \mathrm{ab}$ & 6.7 \\
\hline
\end{tabular}

1 West includes states of Califorria, Kansas, Oklahoma, and Missouri.

${ }^{2}$ LATX includes states of Louisiana and Texas.

${ }^{3}$ Southeast includes states of Florida, Georgia, South Carolina, North Carolina, Tennessee and Kentucky.

wildlife-caused losses. Use of preventative methods varied regionally with the greatest percentage of producers using preventative methods in Mississippi and Arkansas (Table 1). Nationwide, loss prevention methods most frequently cited were: shooting (to scare or kill under U.S. Fish and Wildlife Service permits, $57 \%$ ), vehicle patrol $(55 \%)$, and frightening $(36 \%)$. A smaller proportion of producers tried to disperse roosts $(14 \%)$, modified their management $(10 \%)$ or used other methods $(7 \%)$ to prevent wildlife-caused damages and losses. Roost dispersal was used by $32 \%$ of producers in Mississippi, but only by $6 \%$ in other regions combined.

The dollars spent per operation using loss prevention varied among regions [national median $=\$ 1,000$ and mean $=\$ 6,504 \pm$ 731 (SE)]. Cost of loss prevention was significantly correlated with total sales $(R=$ $0.433, N=616, P<0.001$ ); that is, producers with greater sales spent greater amounts on loss prevention. Overall, catfish producers spent $>\$ 5$ million protecting their operations from wildlife-caused losses (Fig. 3).

\section{Wildlife-Caused Losses}

Overall, $69 \%$ of catfish producers cited wildlife-caused losses of their catfish (Table
2). Producers cited losses to wildlife most frequently in Mississippi and Arkansas; while producers in the Southeast reported losses least frequently.

Birds were most frequently cited as a cause of losses. Double-crested cormorants Phalacrocorax auritus were the most frequently cited species. The next most frequently cited birds were herons $(48 \%)$, of which $42 \%$ cited great blue herons Ardea herodias. Other wildlife cited by $>2 \%$ of all catfish producers are listed in Table 2.

The main problem caused by wildlife was feeding on cattish (67\%) (Table 3). Wildlife also were listed as causing losses by injuring catfish ( $40 \%)$, disrupting the feeding patterns of the catfish (23\%), and damaging structures including roads and dikes $(16 \%)$.

The value of wildlife-caused losses of producers citing losses varied among regions [national median $=\$ 3,500$ and mean $=13,672 \pm 1,253$ (SE)]. Cost of sustained loss was significantly correlated with total sales $(R=0.543, N=615, P<0.001)$; that is, producers with greater total sales tended to report greater losses. The total cost of sustained wildlife-caused losses was the sum of losses cited as sustained in each region adjusted for total sales and summed over the six regions (Fig. 4); overall, catfish 


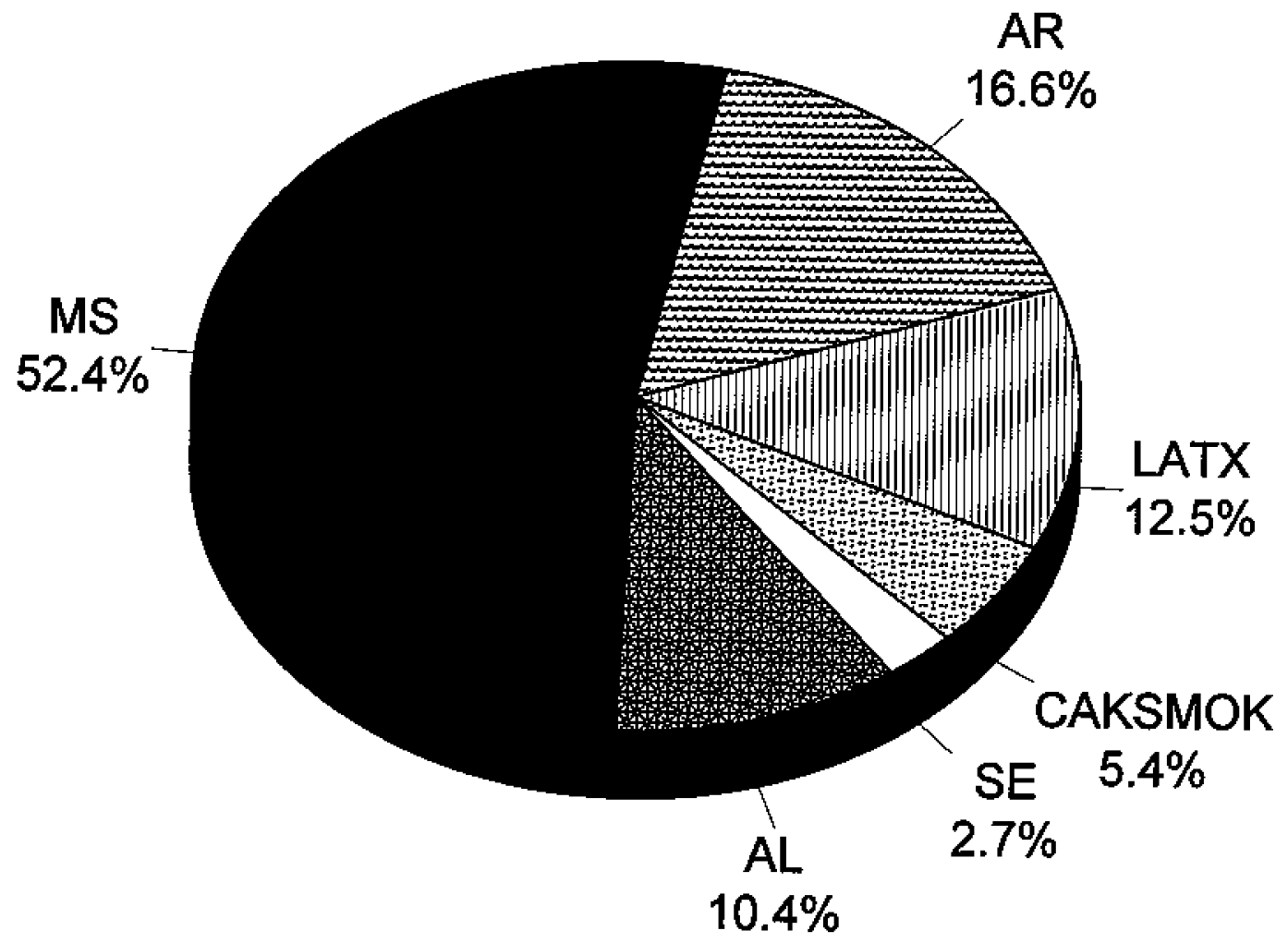

FIGURE 3. Total cost to prevent wildlife-caused losses of catfish among regions in 1996 was $\$ 5.4$ million.

producers lost $\$ 12$ million worth of catfish to wildlife.

Total wildlife costs exceeded $\$ 17$ million, considering both preventative efforts and sustained losses (Fig. 5). Sales of catfish totaled $\$ 425$ million in 1996 (Fig. 6). Total preventative and sustained losses were $4 \%$ of all catfish sales, and would be a substantially greater proportion of profits (sales minus cost of production).

\section{Other Factors Related to Wildife-Caused Losses}

The proportion of producers located $\$ 1.6 \mathrm{~km}$ from a day or night roost or bird refuge varied regionally (Fig. 7). Producers located $\leq 1.6 \mathrm{~km}$ from a night or day roost or bird refuge were more likely to cite wildlife-caused losses $(92 \%)$ than those located farther away ( $63 \%$ cited losses, $M L R=83$, 1 df, $P<0.001$ ). Those near such wildlife refuges were more likely to be familiar with
WS $(67 \%)$ than those not so located $(38 \%$, MLR $=58,1$ df $P<0.001$ ).

\section{Familiarity with Wildlife Services and}

\section{Losses}

More catfish producers ( $44 \%$ ) than other types of agricultural producers (27\% of all agricultural producers in 1994 , Wywialowski 1998) were familiar with the federal Animal Damage Control program (WS). The percentage of producers familiar with WS varied among regions (Fig. 8).

Producers familiar with WS were more likely to have had a loss $(85 \%)$ than those who were unfamiliar with WS (56\%, MLR $=115,1 \mathrm{df}, P<0.001$ ). Those familiar with WS had greater total catfish sales [mean $=\$ 577,640 \pm 59,698$ (SE) vs. mean $=\$ 83,575 \pm 10,154(\mathrm{SE}) ; t=8.2,472 \mathrm{df}$, $P<0.001]$, spent more money trying to prevent losses $[$ mean $=\$ 8,734 \pm 888$ (SE) vs. mean $=\$ 3,327 \pm 1,216(\mathrm{SE}) ; t=3.6$, 
TABLE 2. Percent of catfish producers citing wildife-caused losses of catfish or damage to their catfish farm by regions in 1996 . Wildlife are listed in decreasing order including all wildiffe cited by $\geq 2$ percent of producers nationwide. Regions without the same letter by their percentage differ significantly within rows by the Bonferroni Least Significant Difference Test at $\mathrm{P} \leq 0.05$.

\begin{tabular}{lccccccc}
\hline \multirow{2}{*}{ Wildlife } & \multicolumn{7}{c}{ Region } \\
\cline { 2 - 7 } & West $^{1}$ & LATX $^{2}$ & Arkansas & Mississippi & Alabana & Southeast & All \\
\hline Any & $66.0 \mathrm{~b}$ & $63.2 \mathrm{~b}$ & $74.4 \mathrm{ab}$ & $83.7 \mathrm{a}$ & $68.1 \mathrm{~b}$ & $46.4 \mathrm{c}$ & 69.1 \\
Double-crested Comorant & $30.1 \mathrm{c}$ & $56.3 \mathrm{~b}$ & $65.8 \mathrm{~b}$ & $76.7 \mathrm{a}$ & $49.7 \mathrm{~b}$ & $10.6 \mathrm{~d}$ & 52.9 \\
Heron spp. & $53.4 \mathrm{~b}$ & $36.8 \mathrm{~b}$ & $53.8 \mathrm{~b}$ & $59.0 \mathrm{a}$ & $50.3 \mathrm{~b}$ & $27.8 \mathrm{c}$ & 47.9 \\
Great Blue Heron & $33.0 \mathrm{bc}$ & $30.5 \mathrm{bc}$ & $53.0 \mathrm{bc}$ & $57.0 \mathrm{a}$ & $41.7 \mathrm{~b}$ & $20.5 \mathrm{c}$ & 41.6 \\
Egret spp. & $8.7 \mathrm{c}$ & $10.9 \mathrm{bc}$ & $24.8 \mathrm{ab}$ & $25.7 \mathrm{a}$ & $8.6 \mathrm{bc}$ & $7.3 \mathrm{bc}$ & 15.8 \\
Muskrat & $9.7 \mathrm{~b}$ & $0.6 \mathrm{bc}$ & $7.7 \mathrm{~b}$ & $19.0 \mathrm{ab}$ & $11.7 \mathrm{~b}$ & $5.3 \mathrm{~b}$ & 10.3 \\
White Pelican & $8.7 \mathrm{~b}$ & $11.5 \mathrm{ab}$ & $6.8 \mathrm{~b}$ & $14.7 \mathrm{a}$ & $0 \mathrm{c}$ & $0.7 \mathrm{bc}$ & 8.1 \\
River Otter (n.d.) & 6.8 & 4.0 & 5.1 & 6.0 & 13.5 & 10.6 & 7.5 \\
Waterfowl & $7.8 \mathrm{~b}$ & $1.1 \mathrm{~b}$ & $17.9 \mathrm{a}$ & $2.7 \mathrm{~b}$ & $3.7 \mathrm{~b}$ & $7.9 \mathrm{~b}$ & 5.7 \\
Beaver (n.d.) & 4.9 & 2.3 & 0.9 & 5.3 & 3.1 & 3.3 & 3.6 \\
Turtle (nd.) & 4.9 & 5.7 & 1.7 & 2.0 & 2.5 & 6.0 & 3.6 \\
Gull spp. & $3.9 \mathrm{ab}$ & $1.1 \mathrm{ab}$ & $7.7 \mathrm{a}$ & $3.3 \mathrm{ab}$ & $0 \mathrm{~b}$ & $6.0 \mathrm{ab}$ & 3.4 \\
Raccoon (n.d.) & 5.8 & 4.0 & 3.4 & 0.7 & 2.5 & 2.6 & 2.7 \\
\hline
\end{tabular}

1 West includes the states of Califomia, Kansas, Missouti and Oklahoma.

${ }^{2}$ LATX includes the states of Louisiana and Texas.

${ }^{3}$ Southeast includes the states of Florida, Georgia, South Carolina, North Carolina, Tennessee, and Kentucky.

$496 \mathrm{df}, P<0.001$ ], and sustained greater wildlife-caused losses [mean $=\$ 20,774 \pm$ 2,094 (SE) vs. mean $=\$ 4,293 \pm 480$ (SE); $t=7.7,385 \mathrm{df}, P<0.001]$. When tested as a percent of total catfish sales, patterns were similar but less significant. For percent of preventive cost, those familiar with WS spent an average of $3.2 \%$ ( $\pm 0.5 \mathrm{SE}$ ) of total sales while those unfamiliar with WS spent an average of $6.0 \%( \pm 1.7 \mathrm{SE}, t$
$=1.6,252 \mathrm{df}, P=0.109$ ) of their total sales on damage prevention. For sustained losses as a percent of total sales, those familiar with WS lost an average of $8.9 \%( \pm 1.3$ SE) of total sales while those unfamiliar with WS lost an average of $17.8 \%$ ( \pm 3.5 $\mathrm{SE}, t=2.3,288 \mathrm{df}, P=0.023$ ). This suggests that the size of the operation (as measured by value of total sales) was a major factor influencing familiarity with WS (the

TABLE 3. Types of willife-caused loss or damages reported by catfish producers by regions in I996. Regions without the same letter by their percentage differ significantly within rows by the Bonferroni Least Significant Difference Test at $\mathbf{P} \leq 0.05$.

\begin{tabular}{lccccccc}
\hline & \multicolumn{7}{c}{ Region } \\
\cline { 2 - 8 } & West $^{1}$ & LATX $^{2}$ & Arkansas & Mississippi & Alabama & Southeast & All \\
& $N=103$ & $N=174$ & $N=117$ & $N=300$ & $N=163$ & $N=151$ & 1,008 \\
Type of damage & $(\%)$ & $(\%)$ & $(\%)$ & $(\%)$ & $(\%)$ & $(\%)$ & $(\%)$ \\
\hline Any loss or dannage & $66.0 \mathrm{~b}$ & $61.5 \mathrm{~b}$ & $74.4 \mathrm{ab}$ & $81.7 \mathrm{a}$ & $68.1 \mathrm{~b}$ & $43.7 \mathrm{c}$ & 67.9 \\
Fecding on catfish & $66.0 \mathrm{ab}$ & $60.3 \mathrm{~b}$ & $72.6 \mathrm{ab}$ & $80.3 \mathrm{a}$ & $68.1 \mathrm{ab}$ & $41.1 \mathrm{c}$ & 66.7 \\
Injury of catfish & $43.7 \mathrm{ab}$ & $47.7 \mathrm{a}$ & $58.1 \mathrm{a}$ & $33.3 \mathrm{bc}$ & $44.2 \mathrm{ab}$ & $24.5 \mathrm{c}$ & 40.2 \\
Disrupting feeding & $24.3 \mathrm{ab}$ & $24.7 \mathrm{ab}$ & $37.6 \mathrm{a}$ & $23.3 \mathrm{~b}$ & $21.5 \mathrm{~b}$ & $11.3 \mathrm{~b}$ & 23.3 \\
Damaging structures & $18.4 \mathrm{ab}$ & $6.9 \mathrm{~b}$ & $20.5 \mathrm{a}$ & $23.3 \mathrm{~b}$ & $15.3 \mathrm{ab}$ & $6.6 \mathrm{~b}$ & 15.9 \\
Other & $7.8 \mathrm{a}$ & $0 \mathrm{bc}$ & $0 \mathrm{c}$ & $5.0 \mathrm{a}$ & $0.6 \mathrm{bc}$ & $2.6 \mathrm{a}$ & 2.8 \\
\hline
\end{tabular}

' West includes states of California, Kansas, Oklahoma, and Missouri.

${ }^{2}$ LATX includes states of Louisiana and Texas.

s Southeast includes states of Florida, Georgia, South Carolina, North Carolina, Tennessee, and Kentucky. 


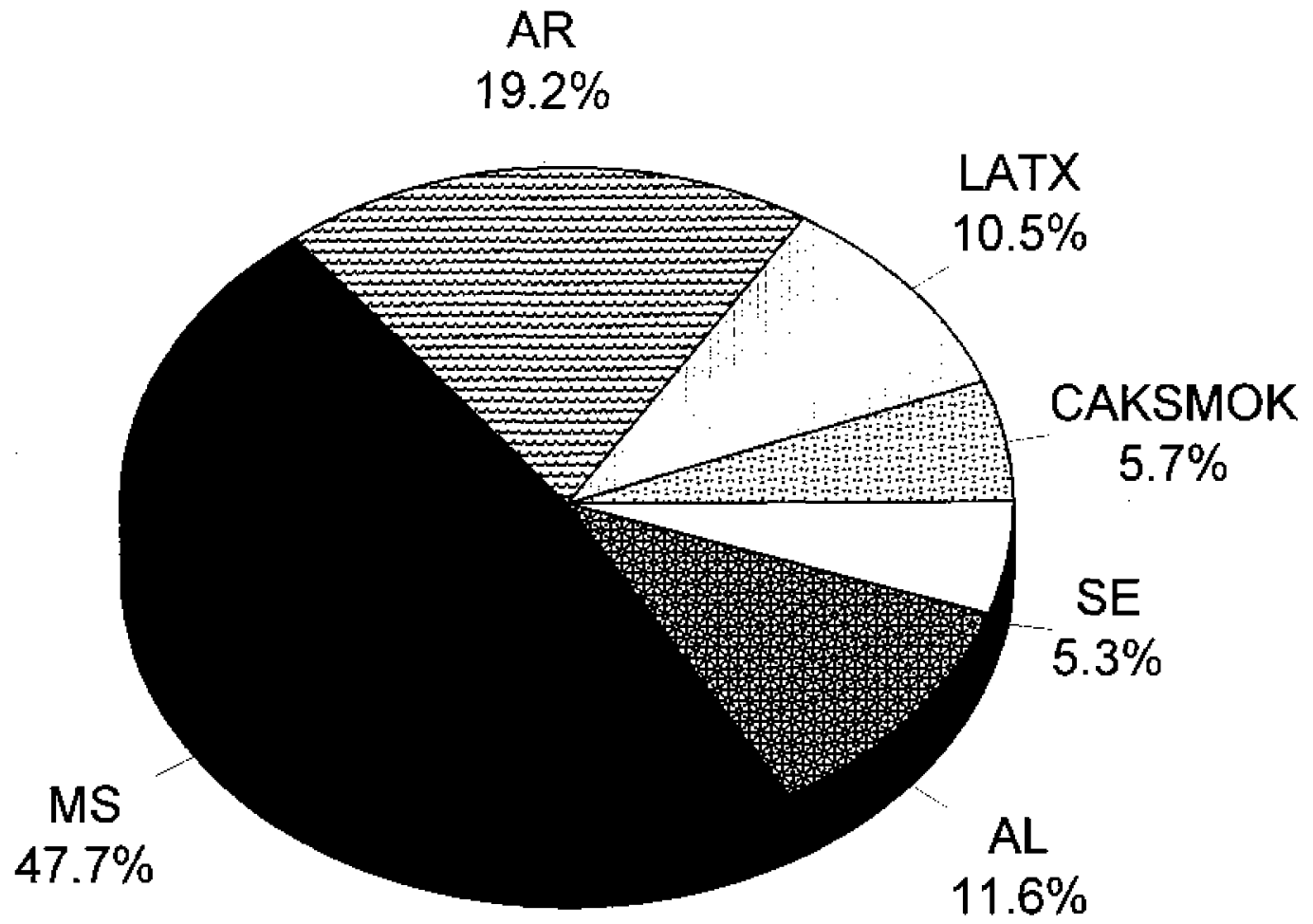

FIGURE 4. Total wildiffe-coused losses of catfish among regions in 1996 was $\$ 11.5$ milliom.

larger the operation, the more likely the awareness of WS); however this relationship is confounded by location (more operations were familiar with WS in Mississippi, Fig. 8), and more production came from Mississippi than all other regions combined (Fig. 6).

\section{Utilization and Effectiveness of Wildlife Services}

Only producers familiar with WS ( $N=$ 447) were asked additional questions about their contact with WS. Of producers familiar with WS (familiar producers), $51 \%$ had contacted WS for assistance on their operation (Table 4); more familiar producers had contacted WS in Mississippi, with the lowest percentage contacting WS in Alabama, although there was overlap among some of the regions. Of producers familiar with WS, $55 \%$ used information that they obtained from WS in their attempts to reduce losses; again, use of WS information was highest in Mississippi even though the proportion statistically overlapped other regions, and the lowest proportions using information were in Alabama and the Southeast region. The clearest difference among the regions was that WS provided direct assistance in 1996 to more producers in Mississippi (59\%) than any other region (26\% averaged across all other regions), and that Mississippi was more likely to use roost dispersal as a damage prevention technique than any other region (Table 1).

This distinct difference between Mississippi and the remaining regions allows the comparison of the utility of WS direct assistance and use of roost dispersal (as identified by WS research) in reducing either loss-prevention costs or wildlife-caused losses for catfish producers. Because operations in Mississippi had greater average catfish sales than the other regions, the proportion of loss-prevention costs and of sustained losses relative to total catfish sales 


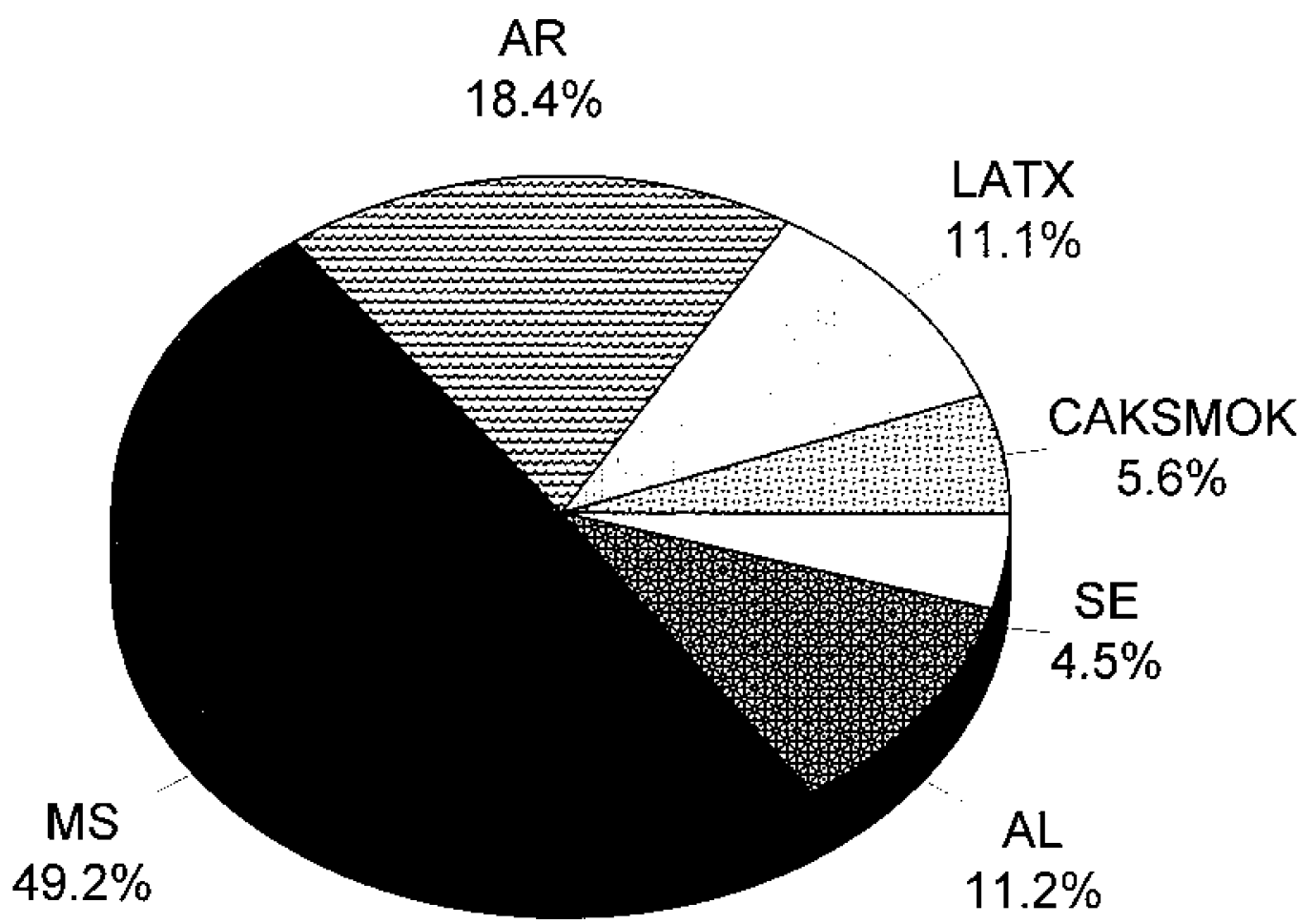

FIGURE 5. Total cost of wildlfe-caused income losses among regions in 1996 was $\$ 17$ million.

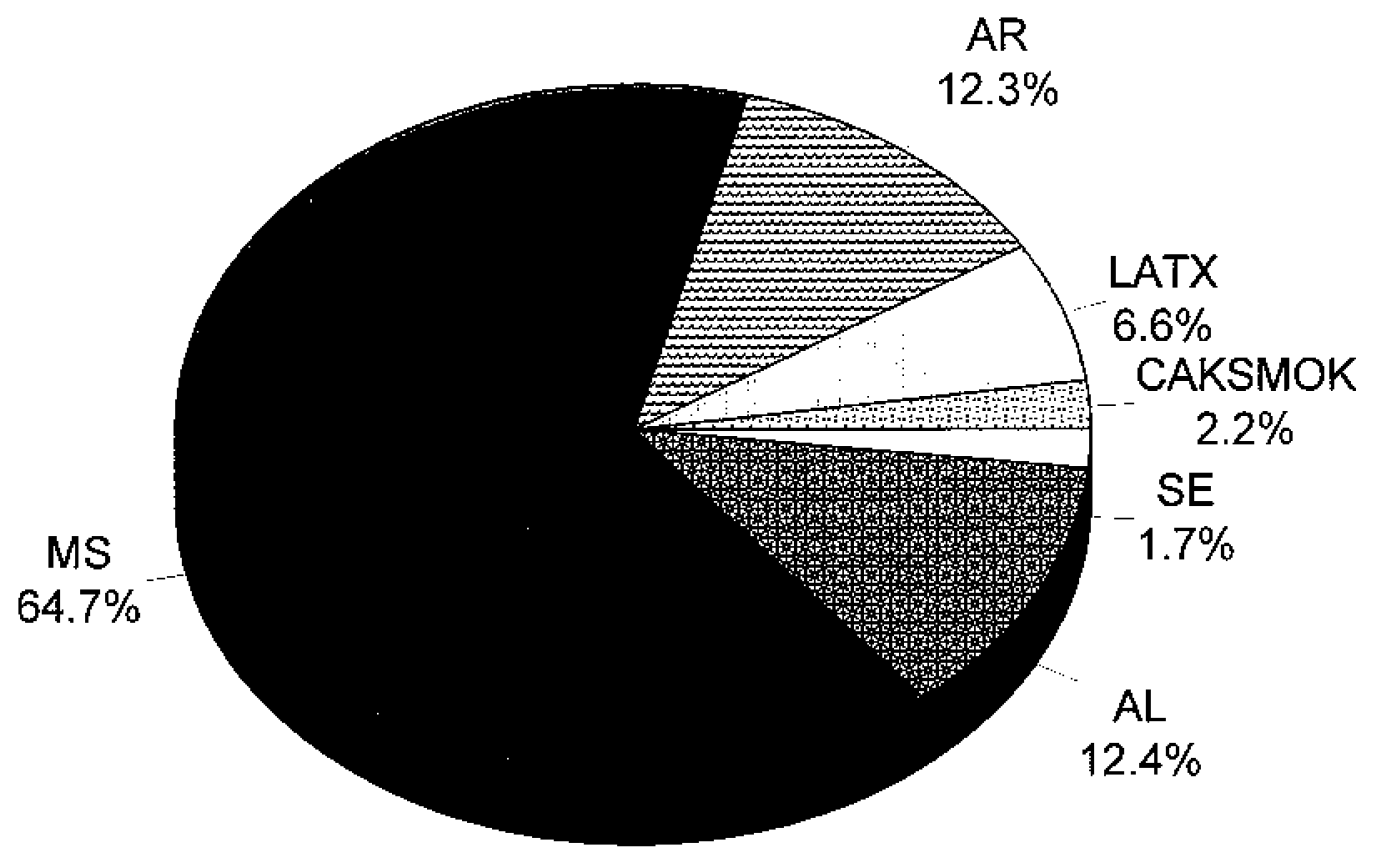

FIGURE 6. Total caffish sates among regions in 1996 was $\$ 425$ million. 


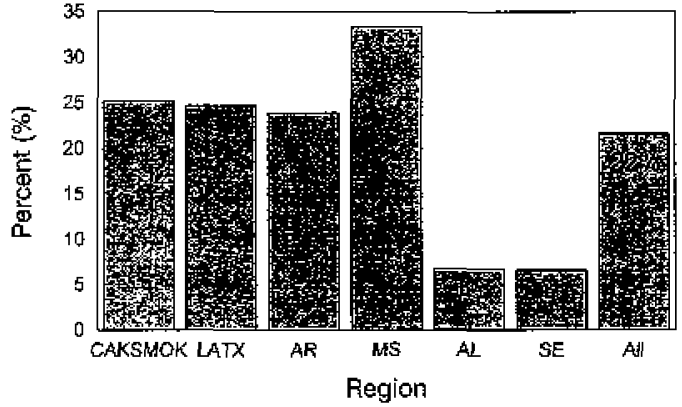

FIGURE 7. Producers $\leq 0.6 \mathrm{~km}$ from the nearest wildlife roost or refuge by region in 1996. Regions without the same letter differ by the Bonferroni test at $\mathrm{P}$ $\leq 0.05$.

on each operation was used for the comparisons.

Cattish producers in Mississippi were proportionately more likely to allocate moderate preventative efforts and sustain lower reported losses. The proportion of preventative costs to total sales expressed as a percent did not differ between Mississippi $[$ mean $=3.4 \% \pm 1.3(\mathrm{SE})]$ and other regions combined $[$ mean $=4.9 \% \pm 0.8$ (SE), $t=1.0, P=0.338$ ]; whereas the proportion of losses to total sales expressed as a percent did differ between Mississippi $[$ mean $=7.5 \% \pm 1.8$ (SE) $]$ and other regions $[$ mean $=15.2 \% \pm 2.3(\mathrm{SE}), t=2.6$, $P=0.009$ ]. Additionally, the proportion of total wildlife-caused costs to producers (preventive costs plus sustained losses) were inversely correlated between Mississippi and all other regions combined (Fig. 9). Viewed another way by using a median

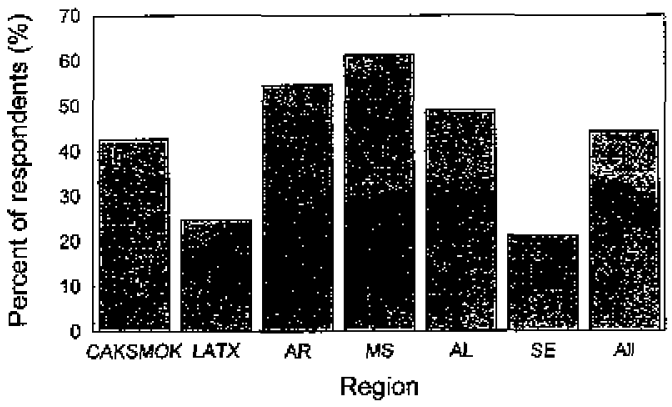

FIGURE 8. Percentage of producers familiar with Wildife Services (WS) in 1996. Regions without the same Letter differ by the Bonferroni test at $\mathrm{P} \simeq 0.05$.

percent cost to split producers in Mississippi versus other states, $67 \%$ of catfish producers in Mississippi had less than the median preventative cost while only $44 \%$ of catfish producers outside Mississippi had less than the median preventative cost (MLR $=62, P<0.001)$. Mississippi catfish producers have had greater support from WS, APHIS, as well as Cooperative State Research, Education, and Extension Service (CSREES) and assistance from Mississippi State University, and their efforts better prevented wildlife-caused losses at less cost than catfish producers in other states. Alternatively, larger operations in Mississippi may have allowed an economy of scale in loss prevention, but producers in Mississippi were proportionately less represented in the lowest percentage of loss prevention categories, while Mississippi producers were proportionately greater in the 3 lowest percentage of sustained losses

TABLE 4. Percent uilization of Wildife Senices as reported by catfish producers familiar with wS $(\mathrm{N}=447)$ by regions in 1996. Regions without the same letter by their percentage differ significantly within rows by the Bonferroni Least Significant Difference Test at $\mathrm{P} \leq 0.05$.

\begin{tabular}{lccccccc}
\hline & \multicolumn{7}{c}{ Region } \\
\cline { 2 - 7 } \multicolumn{1}{c}{ Type of WS assistance } & $\begin{array}{c}\text { West }^{1} \\
(\%)\end{array}$ & $\begin{array}{c}\text { LATX }^{2} \\
(\%)\end{array}$ & $\begin{array}{c}\text { Arkansas } \\
(\%)\end{array}$ & $\begin{array}{c}\text { Mississippi } \\
(\%)\end{array}$ & $\begin{array}{c}\text { Alabama } \\
(\%)\end{array}$ & $\begin{array}{c}\text { Southeast } \\
(\%)\end{array}$ & $\begin{array}{c}\text { All }^{3} \\
(\%)\end{array}$ \\
\hline Contacted WS & $56.8 \mathrm{ab}$ & $48.8 \mathrm{abc}$ & $46.9 \mathrm{abc}$ & $64.1 \mathrm{a}$ & $27.5 \mathrm{c}$ & $34.4 \mathrm{~b}$ & 50.8 \\
Used information from WS & $45.5 \mathrm{~b}$ & $51.2 \mathrm{ab}$ & $56.3 \mathrm{ab}$ & $69.6 \mathrm{a}$ & $37.5 \mathrm{~b}$ & $34.4 \mathrm{~b}$ & 55.3 \\
WS provided direct assistance & $29.5 \mathrm{~b}$ & $32.6 \mathrm{~b}$ & $32.8 \mathrm{~b}$ & $58.7 \mathrm{a}$ & $17.5 \mathrm{~b}$ & $21.9 \mathrm{~b}$ & 39.6 \\
\hline
\end{tabular}

1 West includes states of California, Kansas, Oklahoma, and Missouri.

${ }^{2}$ LATX includes states of Louisiana and Texas.

${ }^{3}$ Southeast includes states of Florida, Georgia, South Carolina, North Carolina, Tennessee, and Kentucky. 


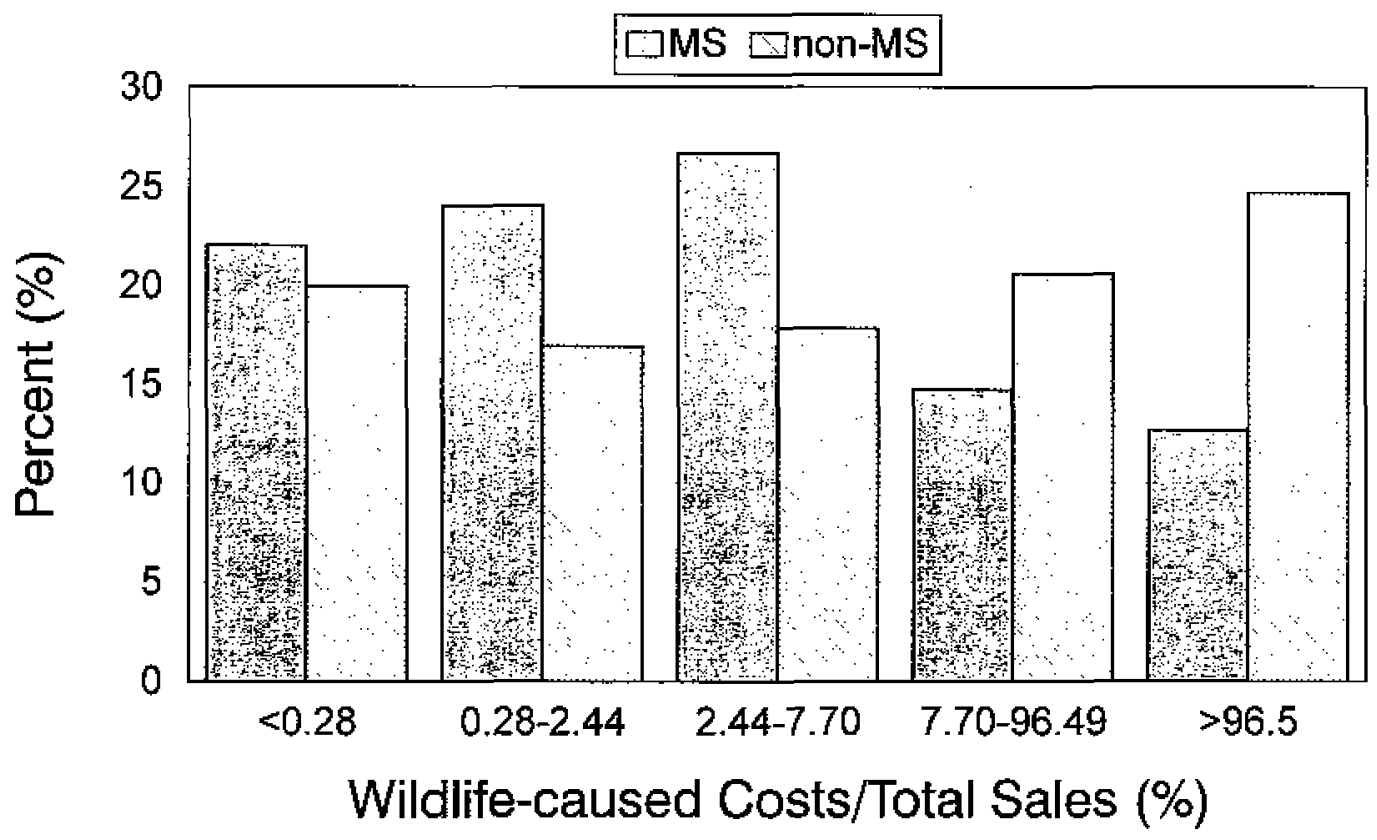

FIGURE 9. Distribution of wildife-caused income loss relative to tolal sales for Mississippi versus other catfish production areas combined in 1996.

categories. This implies that Mississippi producers may have been better informed in their loss prevention strategies, and spent what was necessary to employ the most effective strategies.

\section{Discussion}

\section{Growth of the Catfish Industry and Cormorant Populations}

Given the growth of catfish production in conjunction with growing numbers of double-crested cormorants that winter in the Mississippi delta region (Glahn and Stickley 1995; Glahn et al. 1995) where the majority of catfish production occurs, cormorant-caused losses could be anticipated to be a major problem. Cormorant populations are believed to be at an all time high of 12 million birds and increasing at a rate of 8\% per year (Erwin 1995; Jackson and Jackson 1995; Nisbet 1995; US Department of Interior 1998). In March 1998, the U.S. Fish and Wildlife Service (FWS) issued a final rule that would allow catfish producers in some states to take cormorants that are preying on fish stocks without a FWS permit.

Consistent with the growth of cormorant populations, catfish producers" perception of the problem increased as did the producers' efforts to reduce their losses. In 1988 , $57 \%$ of catfish growers believed cormorants were a problem on their farm and many were dissatisfied with "scaring or frightening devices" strategies (Stickley and Andrews 1989); in this survey for 1996 , $>70 \%$ of Mississippi catfish producers believed that cormorants were causing them substantial losses although $>80 \%$ used some preventative measures, an increase from the $60 \%$ that used preventative measures in 1988 (Stickley and Andrews 1989).

Catfish producer perceptions seem to be grounded in documented potential for wild life to consume catfish. Stickley et al. (1992) found that double-crested cormorants on channel catfish farms caught an average of 5 catfish/cormorant per h. Catch rates went as high as 28 catfish/cormorant per h. If wild gizzard shad Dorosoma ce- 
pedianum occurred in ponds, they seemed to be preferred by cormorants.

\section{Preventative Methods}

The primary preventative technique utilized by producers was vehicle patrol and shooting to scare or kill under FWS permits (Stickley and Andrews 1989; Littauer 1990a, 1990b; Mott and Boyd 1995). Dispersal of night roosts of cormorants has been shown to reduce presence of cormorants at nearby catfish farms, the cost of preventative methods, and the perception of losses for those producers (Mott et al. 1998). Roost dispersal was used most frequently by producers in Mississippi, and Mississippi had proportionately some of the lowest sustained losses and loss prevention costs, consistent with the findings of Mott et al. (1998). No method eliminates all wildlife-caused catfish losses. Exclusion seemed effective in preventing losses for narrow trout raceways (Pitt and Conover 1996), but was prohibitively expensive for some trout producers, and is impractical for catfish producers due to large pond sizes (Littauer 1990a). Other preventative methods used for fish production in raceways (Andelt et al. 1997) may not be applicable for catfish production. Given the growing numbers of catfish and cormorants, preventative techniques have probably been useful in preventing losses from reaching even higher levels.

\section{Economics}

Given the potential consumption of catfish by wild birds, producers may sustain economically significant losses of their catfish crop. Cormorant flocks have been estimated to consume $\$ 13.45 /$ catfish per $h$ of foraging (Stickley et al. 1992). Biomass in the stomachs of great blue herons collected at catfish farms averaged $41 \%$ catfish (Stickley et al. 1995). Hence the large flocks observed can rapidly consume substantial amounts of fish that translate into economic losses for producers. Although Glahn et al. (1995) found that cormorants diets were $>90 \%$ charmel catfish and gizzard shad, Glahn and Brugger (1995) estimated that cormorants may eat approximately $4 \%$ of the standing catfish crop. Based on the results from this survey, wildlife was estimated to cause losses approximating $4 \%$ of the total value of catfish sales in 1996. Keenum and Waldrop (1988) found cost of production of catfish to be $\$ 1.32-1.50 / \mathrm{kg}$ for the smallest to the largest farms. The average sale price of catfish in 1988 was $\$ 1.68 / \mathrm{kg}$ (USDA 1998); this would give a profit range of $11-22 \%$. Hence, the $4 \%$ cost of wildlife damage may be $18-36 \%$ of profits.

Can producers identify the species and amount of losses caused by wildlife? Pitt and Conover (1996) found that trout hatchery managers in the Intermountain West correctly identified the depredating species of wildlife but overestimated the percent of loss, relative to their observations. Additionally, Parkhurst et al. (1992) showed that for trout hatchery managers in Pennsylvania, the birds most frequently identified to cause losses did not cause the greatest losses. However, Brugger et al. (1997) found species causing losses and percent losses to be fairly accurately estimated based on survey of managers and field sampling at trout hatcheries. For catfish producers, the percent estimated loss was low in this survey relative to the percent loss based on the number of catfish put into ponds minus the number of catfish harvested from ponds (USDA 1997), including estimates of losses due to predation, disease or water quality, which are difficult to partition in the often cloudy waters present in catfish ponds.

Losses were least economically significant where WS was best known and most used (Mississippi), although production of catfish was greatest there. Mississippi catfish producers also had greater support from other state and federal agencies, and their efforts better prevented wildlife-caused losses at less cost in comparison to catfish producers in other states. Aquaculture can be a high risk agricultural enterprise due to 
disease, predation and poor water quality (Pomeroy et al. 1994), making any additional losses economically important.

\section{Conclusions}

In summary, most $(68 \%)$ producers tried to avoid wildlife-caused losses of their catfish and spent $>\$ 5$ million nationwide in their efforts. In addition, wildlife-caused losses cost producers $\$ 12$ million in lost production or repair of facilities. Total losses were about $4 \%$ of the total catfish sales of $\$ 425$ million in 1996 , but some producers sustained fewer losses than others. The blanket depredation order on cormorants passed by the U.S. Fish and Wildlife Service in 1998 may help some producers avoid losses, because cormorants were most frequently cited as the main cause of catfish losses. Methods developed by WS, including scare tactics and roost dispersal, may alleviate some of the worst losses. Even if dispersal only redistributes the losses, it may provide some relief for high-loss producers. Producers who received direct assistance from WS in Mississippi averaged lower percentage preventative costs and lower percentage wildlife-caused sustained losses relative to total sales than producers in other states who averaged less direct assistance from WS, and were less likely to use recently researched techniques to reduce losses.

\section{Acknowledgments}

T. Booth, J. Glahn, T. Gregory, D. Hawthome, H. Ishee, D. LeBlanc, P. Mastrangelo, M. Tesky, M. Tobin, and catfish producers and their representatives (especially Bruce Dunlop, Hugh Warren and David Yocom) were instrumental in design of the questionnaire. The WS (ADC), APHIS, USDA funded the survey. E. Welch compiled a computerized literature search. B. Clay, J. Glahn, J. Grimes, G. McCann, P. Mastrangelo, G. Smith, M. Tesky and B. Wagner provided thoughtful comments on this manuscript. Special thanks to all catfish producers who participated in the survey.

\section{Literature Cited}

Andelt, W. F., T. P. Woolley, and S. N. Hopper. 1997. Effectiveness of barriers, pyrotechnics, flashing lights, and Scarey Man for deterring heron predation on fish. Wildlife Society Bulletin $25(3) \div 686-694$.

Bruggers, R., M. Tobia, J. Glahn, and D. T. King. 1997. Evaluating the economic impacts of picivorous predator danage and control methods at finfish aquaculture facilities in the Northeastem States. Final Report to the Northern Regional Aquaculture Facility. Starkville, Mississippi. USA

Erwip, R. M. 1995. The ecology of comorants: some research needs and recommendations. Colonial Waterbirds 18 (Special Publication 1) $240-246$.

Glahn, J. F. and K. E. Brugger. 1995. The impact of doubte-crested comorants on the Mississippi Delta catfish industry: a bioenergetics model. $\mathrm{Co}$ lonial Waterbirds 18 (Special Publication 1):168175.

Glahn, J. F. and A. R. Stickley, Jr. I995. Wintering double-crested cormorants in the Delta region of Mississippi: population levels and their impact on the catfish industry. Colonial Waterbirds 18 (Special Publication 1):137-142.

Glahn, J. F., P. J. Dixson, G. A. Littauer, and R. B. McCoy. 1995. Food habits of double-crested cormorants wintering in the region of Mississippi Delta. Colonjal Waterbirds 18 (Special Publication 1): $158-167$.

Jackson, J. A. and B. J. S. Jackson. 1995. The double-crested cormorant in the south-central United States: habitat and population changes of a feathered pariah. Colonial Waterbirds 18 (Special Publication 1):118-130.

Keenum, M. E. and J. E. Waldrop. 1988. Economic analysis of farm-raised catfish production in Mississippi. Technical bulletin no. 155. Mississippi Agriculture and Forestry Experiment Station, Mississippi State University, Mississippi, USA.

Littatser, G. A. 1990a. Control of bird predation at aquaculnure facilities. Southern Regional Aquaculture Center publication number 402. Mississippi State University, Mississippi, USA.

Littauer, G. A. 1990b. Frightening techniques for reducing bird damage at aquaculture facilities. Southern Regional Aquaculure Center publication number 401. Mississippi State University, Mississippi, USA.

Mott, D. F. and F. L. Boyd. 1995. A review of techniques for preventing comnorant depredations at aquaculture facilities in the southeastern United States. Colonial Waterbirds 18 (Special Publication 1): 176-180.

Mott, D. F., J. F Glahn, P. L. Smith, D. S. Reinhold, K. J. Bruce, and C. A. Sloan. 1998. An evaluation of winter roost harassment for dispersing dou- 
ble-crested cormorants away from carfish production areas in Mississippi. Wildlife Society Bulletin 26(3):584-59l.

Nisbet, I. C. T. 1995. Biology, conservation and management of the double-crested cormorant: symposium summary and overview. Colonial Waterbirds 18 (Special Publication 1):247-252.

Parkhurst, J. A., R. P. Brooks, and D. E. Arnold. 1992. Assessment of predation at trout hatcheries in central Pennsylvania. Wildlife Society Bulletin 20(4):411-419.

Pitt, W. C. and M. Conover. 1996. Predation at Intermountain West fish hatcheries. Journal of Wildlife Management 60(3):616-624.

Pomeroy, R., S. M. Carlier, and C. E. Cortis, Jr. 1994. Profitability of catfish on a representative multiple enterprise farm in the southeasten United States under conditions of risk. Pages 315-330 in M. Antona, J. Catanzano, and J. G. Sutinen, editors. Proceedings Sixth Conference of the International Institute of Fisheries, Economics and Trade. Ifremer Cent. Paris, Issy Les Moulineaux, France.

Stickley, A. R., Jr. and K. J. Andrews. 1989. Survey of Mississippi catfish farmers on means, effort, and costs to repel fish-eating birds from ponds. Pages 105-109 in S. R. Craven, editor. Proceedings of the Fourth Eastern Wildlife Damage Control Conference. Madison, Wisconsin, USA.
Stickley, A. R., Jr., G. L. Warrick, and J. F. Glahn. 1992. Impact of double-crested cormorant depredations on channel cattish farms. Journal of the World Aquaculture Society 23(3):192-198.

Stickley, A. R, Jr., J. F. Glahn, J. O. King, and D. T. King. 1995. Impact of great blue heron depredations on channel carfish farms. Journal of the World Aquaculture Society 26(2):194-199.

United States Department of Agriculture. 1997. Reference of 1996 U. S. cattish management practices, part II. Animal and Plant Health Inspection Service, Veterinary Services, Centers for Epidemiology and Animal Health, National Animal Health Monitoring System, Fort Collins, Colorado, USA.

United States Department of Agriculture. 1998. Agricultural statistics 1998. National Agricultural Statistics Service. ISBN O-16-049218-1. U. S. Government Printing Offce, Superintendent of Documents, Washington, D.C., USA.

United States Department of Interior. 1998. Migratory bird permits; Establishment of a depredation order for the double-crested cormorant. March 4, 1998. Department of Interior, Fish and Wildlife Service. 50 CFR, part 21. RIN 1018-AE11. Final Rule. Federal Register 63(42): 10550-10561.

Wywialowski, A. P. 1998. Are wildlife-caused losses of agriculture increasing? Proceedings of the Vertebrate Pest Conference 18:363-370. 